Article

\title{
Are Landscape Restoration Interventions Sustainable? A Case for the Upper Tana Basin of Kenya
}

\author{
Fred Kizito ${ }^{1,2, *}$, Jane Gicheha ${ }^{3}$, Abdul Rahman Nurudeen ${ }^{2}\left(\mathbb{D}\right.$, Lulseged Tamene ${ }^{4}$, Kennedy Nganga ${ }^{3}(\mathbb{D}$ \\ and Nicholas Koech ${ }^{3}$ \\ 1 Alliance for Biodiversity-CIAT, Accra PMB LG 56, Ghana \\ International Institute of Tropical Agriculture, Tamale PMB TL 06, Ghana; A.Nurudeen@cgiar.org \\ Alliance for Biodiversity-CIAT, Nairobi 823-00621, Kenya; janengicheha@gmail.com (J.G.); \\ ken.w.nganga@gmail.com (K.N.); koechnicholas@gmail.com (N.K.) \\ 4 Alliance for Biodiversity-CIAT, Addis Ababa P.O. Box 5689, Ethiopia; Lt.desta@cgiar.org \\ * Correspondence: f.kizito@cgiar.org; Tel.: +233-50-9401148
}

Citation: Kizito, F.; Gicheha, J.; Nurudeen, A.R.; Tamene, L.; Nganga, K.; Koech, N. Are Landscape Restoration Interventions Sustainable? A Case for the Upper Tana Basin of Kenya. Sustainability 2021, 13, 10136. https://doi.org/ $10.3390 /$ su131810136

Academic Editor: Ivo Machar

Received: 19 March 2021

Accepted: 15 July 2021

Published: 10 September 2021

Publisher's Note: MDPI stays neutral with regard to jurisdictional claims in published maps and institutional affiliations.

Copyright: (c) 2021 by the authors. Licensee MDPI, Basel, Switzerland. This article is an open access article distributed under the terms and conditions of the Creative Commons Attribution (CC BY) license (https:// creativecommons.org/licenses/by/ $4.0 /)$.

\begin{abstract}
Landscape restoration initiatives often have the potential to result in environmental gains, but the question of whether these gains are sustainable and how they are linked to other community needs (social, productivity and economic gains) remains unclear. We use the Sustainable Intensification Assessment Framework (SIAF) to demonstrate how environmental benefits are linked to productivity, environment, social, human, and economic components. Using the SIAF, the standardization of relevant indicators across multiple objectives provided a contextual representation of sustainability. The study assessed the overall gains resulting from the measured indicators of sustainable land management (SLM) practices and their relationship to the multiple domains of the SIAF. We present a unique case for SLM options using a combined-methods approach where biophysical, socio-economic, and citizen science help assess the sustainability of the interventions. Using a participatory approach with farmers, land restoration options were conducted in four target micro-watersheds for 3 years (2015-2017). Co-developed restoration measures at the landscape level within the four micro-watersheds (MW1-MW4) resulted in a substantial increment (50\%) for all treatments (grass strips, terraces, and a combination of grass strips and terraces) in soil moisture storage and increased maize and forage production. We demonstrate that SLM practices, when used in combination, greatly reduce soil erosion and are profitable and sustainable while conferring livelihood benefits to smallholder farmers.
\end{abstract}

Keywords: landscape restoration; livelihood benefits; sustainable intensification

\section{Introduction}

Sustainable land management (SLM) is critical for maintaining the environmental integrity of landscapes, which translates into improved livelihood benefits for farmers in the Upper Tana Basin of Kenya. Thomas et al. [1], in their "Soil and Water Conservation Manual for Kenya", give an overview and a technical description of the key options for smallholder farmers. The WOCAT [2] work on "Where the land is greener" provides 42 SLM cases that include, among others, cases of grass strips, cover crops, terraces, agroforestry, gully rehabilitation, and grazing land management.

A review of the status of the erosion in the Upper Tana Basin of Kenya [3] highlights estimates of erosion under different land management scenarios where SLM options resulted in environmental benefits. This region has undergone substantial changes, and large areas of forests were replaced by agricultural fields since the 1970s [4]. The conversion of forest to agricultural land, leads to changes in hydrology [5]. Maingi and Marsh [6] performed a study to quantitatively document the extent and continuity of the riverine forests and associated land covers along the Tana river floodplain. The results showed a significant decline in riverine forest between 1989 and 1996 due to the cutting of the trees 
for charcoal and creating farmland for irrigated agriculture [6], which in turn was causing soil erosion. According to an erosion report made for WRMA, the erosion from catchments draining from the Aberdare highlands was the most severe [7]. Numerous partners, such as KenGen, have conducted pilot projects to reduce the erosion within sub-catchments of the Maragua River, because erosion is severe and can greatly affect these farming systems, with annual crops such as maize, beans, potatoes, and vegetables [8].

The work conducted in this study focused on landscape activities of smallholder farmers who are located both upstream and downstream of the Upper Tana Basin and on how their SLM activities address severe erosion within the agricultural landscapes. The SLM practices considered in this study were limited to three low-cost measures: forage grass strips, terraces, and the combination of both practices (grass strips and terraces) and control areas without SLM practices. We present these as four treatments across four micro-watersheds within the Upper Tana Basin. We then test the sustainability of these interventions within the lens of the Sustainable Intensification Assessment Framework (SIAF) [9].

\section{Materials and Methods}

\subsection{Study Area}

The Upper Tana Basin of Kenya is an area that is very prone to soil erosion and covers approximately $17,000 \mathrm{~km}^{2}$ and is home to 5.3 million people [10]. The basin covers Mount Kenya and the Aberdare highlands, with elevations ranging from $4500 \mathrm{~m}$ at Mount Kenya to about $400 \mathrm{~m}$ above sea level in the east of the catchment [11]. There are two rainy seasons, and rainfall is relatively high, with an average annual rainfall of about $2000 \mathrm{~mm}$ at higher altitudes [12].

\subsection{Landscape Restoration Interventions}

As depicted in Figure 1 and Table 1, four clusters of micro-watersheds (MW1 through MW4) are located in sets within a larger sub-watershed, with one to two treatments (green) and one control (purple), and with similar soils, crops, and local weather. The treatment micro-watersheds represent areas with SLM activities for erosion control. The SLM activities were conducted in three priority sub-watersheds (Figure 1), namely: ThikaChania, Maragua, and Sagana-Gura. Extensive field- and household-level surveys were conducted to gain a broad understanding of farmers' demographic characteristics and assess how restoration efforts translate into livelihood benefits for smallholder farmers. Eight farmers implemented SLM practices (forage grass strips, terraces, and a combination of both treatments- grass strips and terraces). The control represents areas where no SLM was conducted, thus forming a Before-After-Control-Impact (BACI) design. In the context of this study, the control areas were plots that did not have SLM measures, hence acting as bare plots with no SLM measures, and were used as a comparison to the areas that had SLM practices. Data collected from micro-watersheds MW1 through MW4 included the GPS co-ordinates of each plot, soil infiltration data, rainfall, soil moisture storage, runoff, the sediment retained, and crop yield data. Erosion and runoff detectors quantified how much sediment was running off the landscape, as depicted in Figure 2. Fieldwork enabled the comparison of how different land management practices reduce soil erosion either alone or in combination compared to the areas without SLM options.

The terraces were in the form of bench terraces, which are almost level steps, constructed on the contour and separated by embankments known as risers, with the purpose of reducing the slope of cultivated land, reducing the surface runoff and increasing the infiltration of water into the soil [1]. These were formed through excavation, although they eventually develop from grass strips as they trap soil and sediment over time. The data collection on sediment retention avoided the disturbance period because these experimental preparations typically took place 3 months before data collection. This allowed the experimental soil calibration troughs to normalize and settle before data collection. 


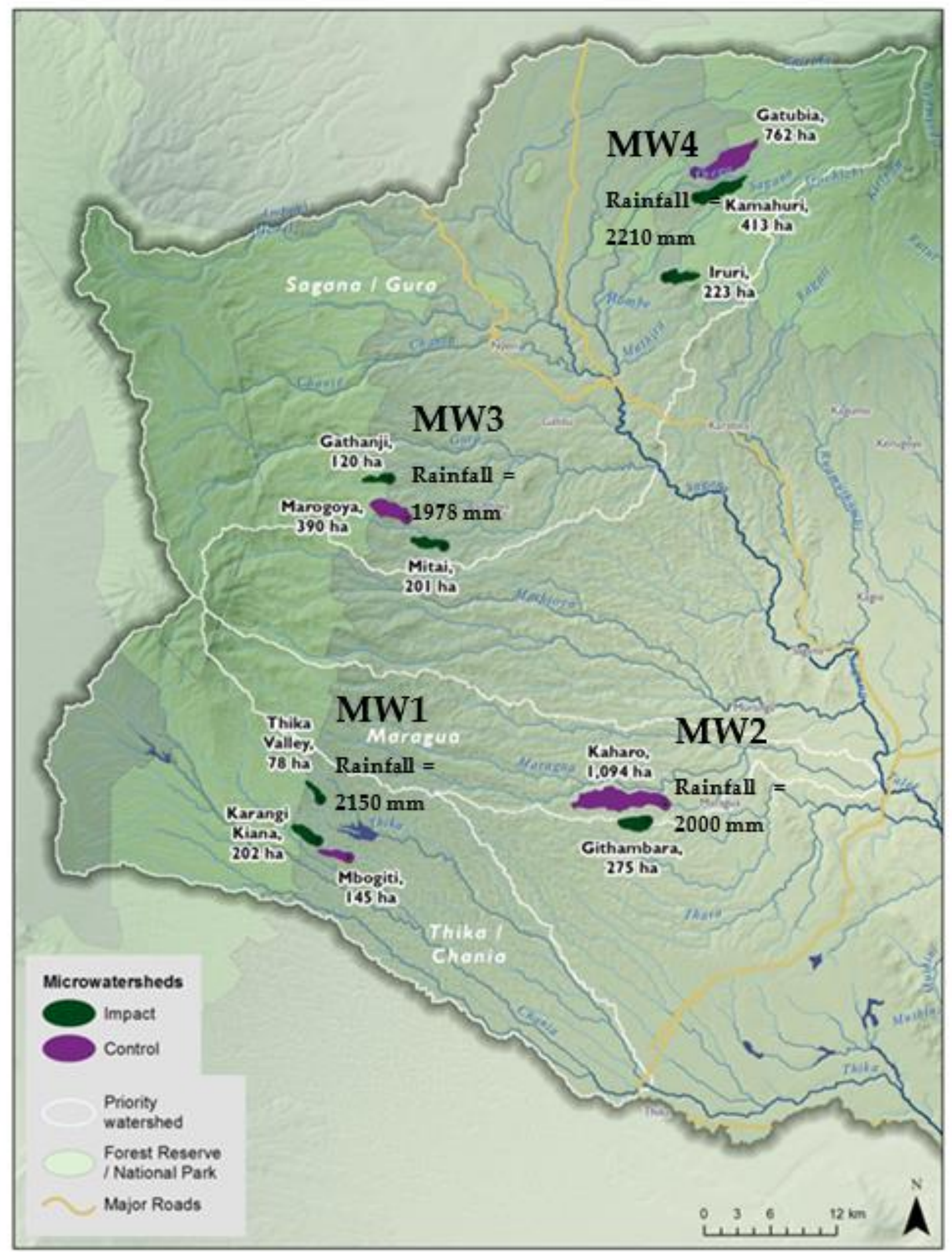

Figure 1. A map of the Upper Tana in Kenya showing the location of the three priority sub-watersheds (Thika-Chania, Maragua, Sagana-Gura). Also shown are the location of four micro-watersheds (MW1, MW2, MW3, and MW4) in each cluster and the type (control or impact) of each micro-watershed with annual average rainfall amounts for 2015-2017. 
Table 1. Farmers, treatments and crops involved in the study within four micro-watersheds in the Upper Tana Basin.

\begin{tabular}{ccccccc}
\hline Farmer & $\begin{array}{c}\text { Micro } \\
\text { Watershed } \\
\text { Name }\end{array}$ & $\begin{array}{c}\text { Micro- } \\
\text { Watershed } \\
\text { Code }\end{array}$ & $\begin{array}{c}\text { Elevation } \\
\mathbf{( m )}\end{array}$ & $\begin{array}{c}\text { Slope- } \\
\text { Aspect }\end{array}$ & SLM Practice & Crops Grown \\
\hline 1 & Kirangi Kiana & MW1 & 2078 & NFS & No SLM & Maize, Beans \\
2 & Mbogiti & MW1 & 2052 & SFS & Terrace \& Grass strip & Maize, Beans \\
3 & Githambara & MW2 & 1975 & NFS & Terrace \& Grass strip & Maize, Bananas \\
4 & Kahuro & MW2 & 1959 & SFS & No SLM & Maize, Bananas \\
5 & Gathanji & MW3 & 1657 & NFS & No SLM & Maize, Cabbages \\
6 & Marogoya & MW3 & 1665 & SFS & Terrace \& Grass strip & Maize, Cabbages \\
7 & Kimakia & MW4 & 2421 & NFS & Terrace \& Grass strip & Potatoes, Maize \\
8 & Kimakia & MW4 & 2439 & SFS & Terrace \& Grass strip & Potatoes, Maize \\
\hline
\end{tabular}
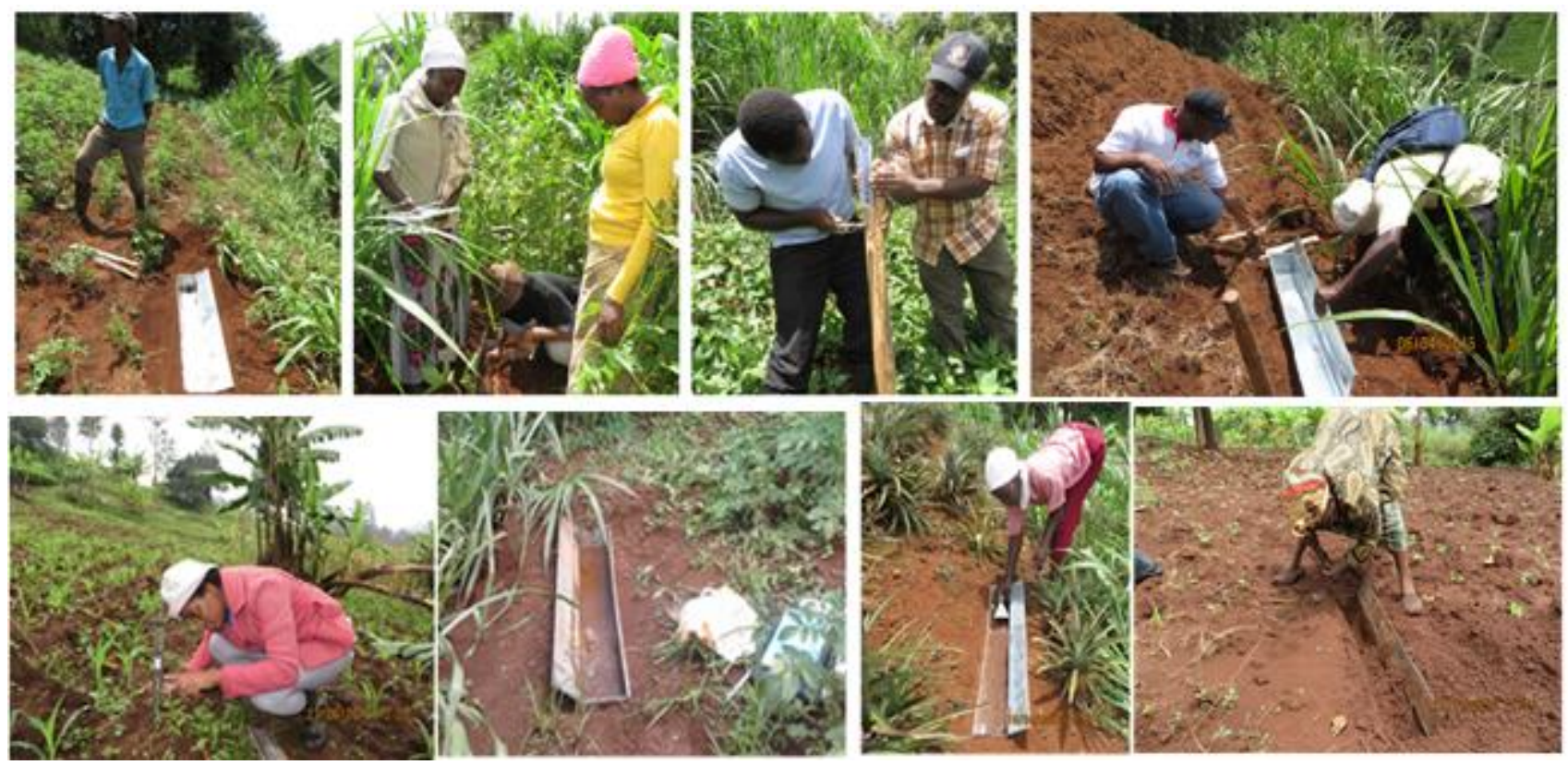

Figure 2. Runoff measurements were compared from representative sites prior to and again after conservation interventions were installed at specific areas within farmer fields, which were selected for monitoring erosion, rainfall, and runoff. Field technicians and farmers assisted in recording data for the calibrated troughs, maintained them, and conducted infiltration measurements.

\subsubsection{Evaluation of Sustainability of Landscape Interventions}

This study co-opted the SIAF developed by Musumba et al. [9] to assess the sustainability of SLM practices for soil and water conservation within cropping systems in the Upper Tana Basin. We present a conceptual illustration of how we assessed the sustainability of landscape restoration interventions (Figure 3). The SIAF provided a consistent and systematic guide for the selection and measurement of indicators under the five domains (Productivity, Economic, Environment, Human condition, and Social) in order to assess the sustainability of the interventions [13] with an ability to have a measurable impact around environmental integrity and livelihoods (Figure 3). Recent work from Abdul Rahman et al. 2020 provides three critical steps relevant for the use of the SIAF: (i) The selection and measurement of indicators under the five domains; (ii) The standardization of values through the transformation of measured indicators into unit-less scores. This brings indicators with different units to one scale; and (iii) The aggregation of indicators under each of the five domains in order to have a relative comparison of how the different domains are performing. 


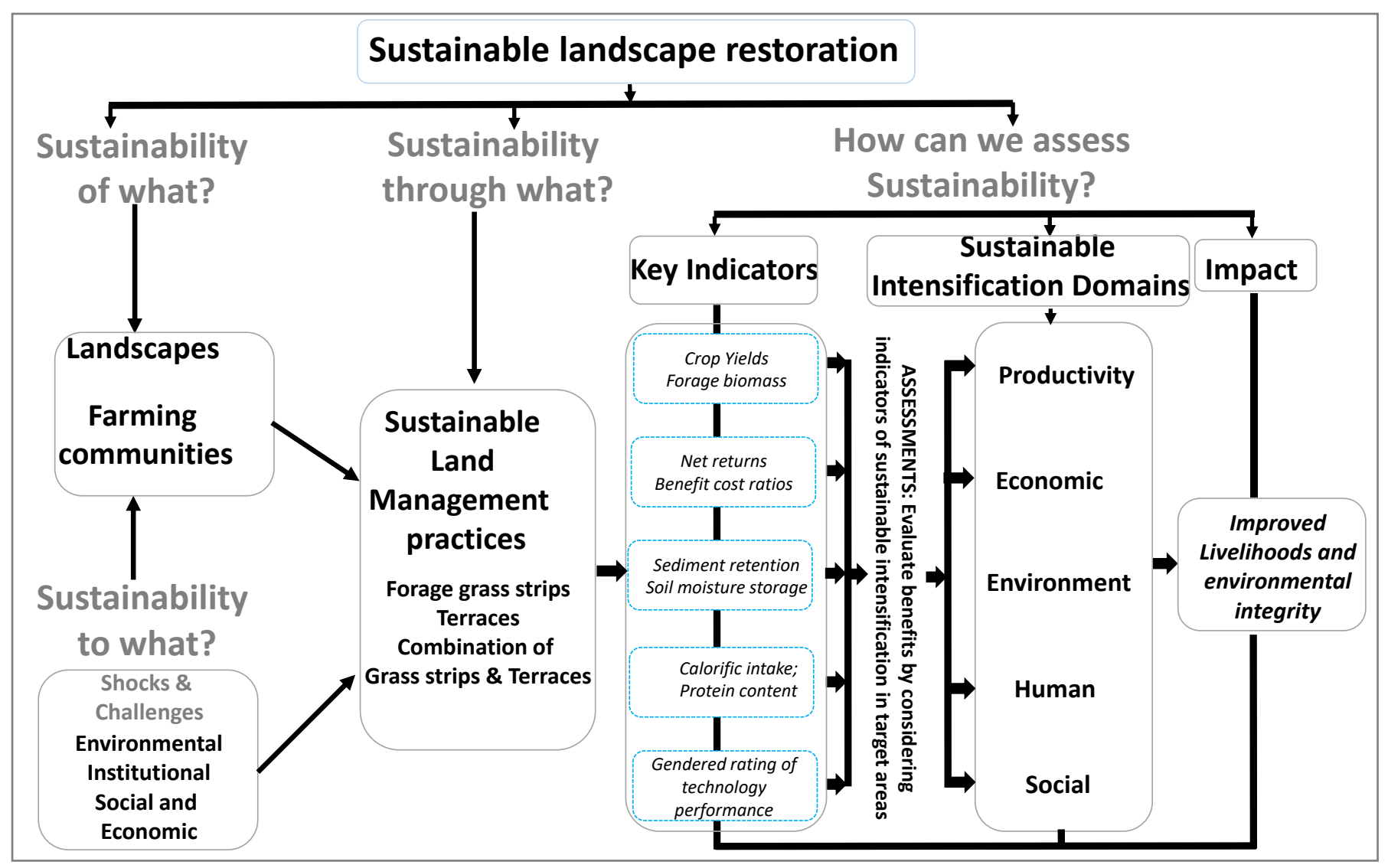

Figure 3. Conceptual illustration of sustainable landscape restoration with the sustainable intensification assessment framework highlighting the key indicators used in the study.

\subsubsection{Selection and Measurement of Indicators by Domains \\ Productivity}

Maize yields and forage grass biomass were the indicators selected for productivity, and data were obtained from both household level participatory surveys (2015-2017) and experimental field data sets on the same pool of farmers (Table 1) within the four micro-watersheds MW1 through MW4.

\section{Economic}

For the economic domain, we calculated both the net income and benefit cost ratio $(\mathrm{BCR})$ as our indicators to determine the profitability of the landscape interventions. The calculations included the total cost of production, which entailed the labor for land preparation, planting, application of fertilizers, thinning, weeding, formation of terraces, planting of forage grass strips, and reinforcements and the maintenance of both terraces and forage grass strips as soil and water conservation measures, harvest, and storage. The information was predominantly based on key informant interviews. The key informants were extension agents and farmers participating in the trials. The sales revenue was calculated as the product of the total yield (tons/ha) with the prevailing market price. The net revenue was the difference between the sales revenue and the total cost of production. The benefit-cost ratio was the quotient of the sales revenue to the total cost of production.

\subsubsection{Environment}

Two indicators were used for this domain: the sediment retained in the landscape and the soil moisture storage. Over the course of 3 years, on-farm monitoring studies measured the sediment runoff, erosion, and soil moisture storage within the cropping root zone for the control areas with no SLM practices and for the areas with grass strips, terraces as well 
as the ones that had a combination of terraces and grass strips. The volumetric soil water content was continuously monitored at hourly intervals. Since daily moisture values can be very variable depending on the season, measurements were taken, such as the rainy period (before cropping, during cropping, and after cropping) in the four different treatments, using dielectric soil water content sensors $\left(\mathrm{ECH}_{2} \mathrm{O}\right.$ Probe; Decagon Devices Inc, Pullman, WA, USA). These were calibrated gravimetrically in the field and installed at depths of $20 \mathrm{~cm}$ and $40 \mathrm{~cm}$. Probe data were logged at hourly intervals with an automated hobo data logger. Real-time moisture measurements permitted the quantification of incoming and outgoing water fluxes into the rooting zone of the treatments following the principle of mass conservation. This allowed for the assessment of the overall root zone soil moisture storage.

\subsubsection{Human}

In this domain, we used two metrics, namely the total calories and the protein content within food grown under each treatment as a measure of food security and nutrition indicators. The quantity of grain yield produced by a treatment contributed to the total calorie and protein production. We used conversion factors derived from the United States Department of Agriculture's Agriculture Research Services National Nutrient Database for Standard Reference to estimate the food security and nutritional values of each treatment (https:/ / ndb.nal.usda.gov/ndb/foods/show/16087 (accessed on 20 January 2020) [14].

\subsubsection{Social}

Based on Focus Group Discussions (FGDs), farmers shared their experiences and rated the performance of the different treatments. The evaluation of the treatments was done in two groups, separating the male from the female farmers. This was done to allow the female farmers to feel comfortable among themselves to express their opinions about the technologies. The preference of farmers for the treatments were estimated in percentages.

\subsection{Statistical Analysis}

The General Linear Model of the Statistical Analysis System for Windows [15] was used to analyze productivity, economic, environment, and human domains data. The respective years of the experimentation (2015-2017) were considered as replicates in the statistical analysis. The micro-watersheds MW1 through MW4 were considered as experimental blocks, and the treatments were replicated across the blocks in the statistical analysis. The least significant difference (LSD) was used to separate treatment means of significant differences at the probability level of $0.05(p<0.05)$.

\subsection{Data Standardization and Sustainability Indices}

We conducted indicator aggregation and sustainability indexing based on the minimum and maximum limits for each measured indicator and used it to convert the indicator values into unit-less scores following the standardization methodology by Rahman et al. [9,13]. We determined the minimum and maximum limits for each measured indicator as a way of standardization and used it to convert the indicator values into unitless scores using Equation (1) [13]:

$$
S_{\mathrm{i}}=\frac{D_{\mathrm{a}}-D_{1}}{D_{\mathrm{h}}-D_{\mathrm{l}}}
$$

where $S_{i}$ is the ith indicator, $D_{\mathrm{a}}$ is the actual data value of the indicator in the dataset, $D_{1}$ is the lowest possible data value of the indicator, and $D_{\mathrm{h}}$ is the highest possible data value of the indicator. The scored values were in the range of 0 to 1, with 0 as the lowest and 1 as the highest indicator strength. The transformed values of indicators (scores) were aggregated under each of the five domains using the arithmetic mean approach [13]. The scores for each of the five sustainable intensification domains were used to calculate the sustainability indices for the treatments. Considering the five sustainable intensification domains as a 
pentagon with three triangles (Figure 4), we found the area of each of the three triangles and calculated the sustainability index as the sum of the areas for the three triangles $[9,13]$ :

$$
\begin{gathered}
T_{1}=\frac{\sqrt{3}}{4}(\mathrm{SP}+\mathrm{SH}+\mathrm{HP}) \\
T_{2}=\frac{\sqrt{3}}{4}(\mathrm{HP}+\mathrm{HEv}+\mathrm{EvP}) \\
T_{3}=\frac{\sqrt{3}}{4}(\mathrm{PEv}+\mathrm{PE}+\mathrm{EEv})
\end{gathered}
$$

where $i$ is 1,2 , and 3 . In order to have a sustainable system, the sustainability index should always be positive and greater than one; the higher the value, the more sustainable the system $[9,13]$.

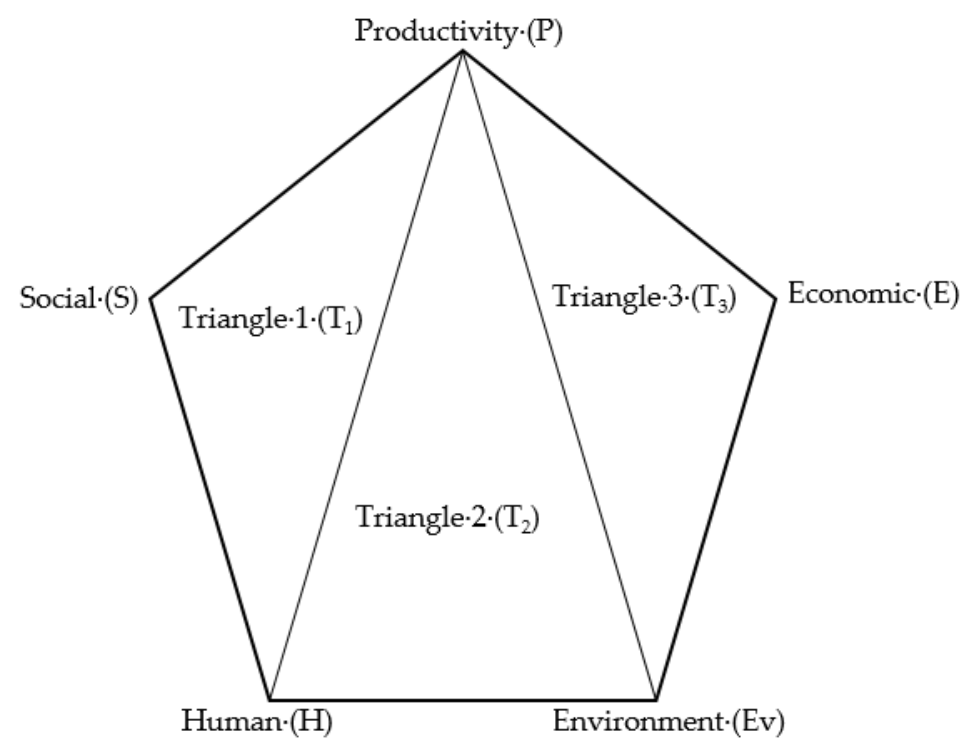

Figure 4. Schematic representation of the pentagon with triangles (Adapted from [13]).

\section{Results}

The measured indicators showed significant responses to the different SLM options across the pooled four micro-watersheds, as depicted in Table 2. We present the disaggregated results by domains for the SIAF at the Upper Tana watershed level.

\subsection{Productivity}

The yields of crops as listed in Table 2 showed that there were significant differences among the various treatments, notably with the forage grass strips and terraces showing a degree of interaction effects $(p<0.05)$. The terraces and forage grass strips showed significant differences regarding the control areas without SLM practices. The combination of forage grass strips and terraces showed the highest productivity levels.

\subsection{Economic}

Given that the combination of forage grass strips and terraces showed the highest productivity levels, this translated into economic gains, as depicted by the net income and the benefit cost ratios (Table 2). There were no significant differences among the three SLM treatments, but their yields were significantly different from those of the control without SLM options. The labor costs for establishing and maintaining the bench terraces was about $25 \%$ higher than the forage grass strips. 
Table 2. Sustainable land management options on measured indicators of SIAF: Productivity, Economic, Environment, Human Condition, and Social domains over four micro-watersheds as replicates.

\begin{tabular}{|c|c|c|c|c|c|c|c|c|c|c|}
\hline Domain & Productivity & & Economic & & Environme & & $\begin{array}{l}\text { Human } \\
\text { Condi- } \\
\text { tion }\end{array}$ & & Social & \\
\hline Indicator & Crop yield & $\begin{array}{c}\text { Forage } \\
\text { yield }\end{array}$ & $\begin{array}{c}\text { Net } \\
\text { Income }\end{array}$ & BCR & $\begin{array}{l}\text { Sediment } \\
\text { retention }\end{array}$ & $\begin{array}{l}\text { Soil } \\
\text { moisture } \\
\text { storage }\end{array}$ & Calories & Protein & $\begin{array}{c}\text { Technology } \\
\text { Rating } \\
(\%)\end{array}$ & \\
\hline $\begin{array}{c}\text { Metric } \\
\text { Treatments }\end{array}$ & Tons/ha & Tons/ha & USD & & $\%$ & $\mathrm{~mm}$ & $\mathrm{KCal} / \mathrm{ha} / \mathrm{yr}$ & $(\mathrm{g} / \mathrm{ha}) \times 10^{8}$ & Male & Female \\
\hline No SLM & $16.8 \mathrm{~b}$ & 0 & $232.1 \mathrm{~b}$ & $1.4 \mathrm{c}$ & $9 \mathrm{~d}$ & $33 \mathrm{~b}$ & $3.7 \mathrm{c}$ & $1.8 \mathrm{c}$ & 12 & 8 \\
\hline $\begin{array}{l}\text { Grass } \\
\text { strips }\end{array}$ & $36.1 \mathrm{ab}$ & $51 \mathrm{a}$ & $950.7 \mathrm{a}$ & $3.9 \mathrm{~b}$ & $25.5 c$ & $76.5 \mathrm{ab}$ & $9.2 \mathrm{~b}$ & $4.5 \mathrm{~b}$ & 22 & 29 \\
\hline $\begin{array}{c}\text { Terraces } \\
\text { Grass }\end{array}$ & $36.2 \mathrm{ab}$ & $57 \mathrm{a}$ & $763.6 \mathrm{a}$ & $3.6 \mathrm{~b}$ & $39.75 b$ & $71.3 \mathrm{ab}$ & $9.2 \mathrm{~b}$ & $3.8 \mathrm{~b}$ & 27 & 18 \\
\hline $\begin{array}{l}\text { strips \& } \\
\text { Terraces }\end{array}$ & $57.5 \mathrm{a}$ & $72 \mathrm{a}$ & $1084.0 \mathrm{a}$ & $4.6 \mathrm{a}$ & $48.5 \mathrm{a}$ & $96.8 \mathrm{a}$ & $14.7 \mathrm{a}$ & $7.3 \mathrm{a}$ & 39 & 45 \\
\hline S.E.M & 8.31 & 15 & 187.08 & 0.69 & 8.64 & 13.32 & 2.24 & 1.13 & - & - \\
\hline$p$-value & 0.0031 & 0.0052 & $<0.0001$ & 0.0025 & $<0.0001$ & 0.0011 & 0.0011 & 0.0002 & - & - \\
\hline
\end{tabular}

Values with the same letter(s) in the columns under a factor are not significantly different from each other according to the least significant difference (lsd) test. 1 US\$ = 105 K Shs. S.E.M: The standard error of the sample mean.

\subsection{Environment}

As indicated in Figure 5, the control areas within the micro-watersheds that had no SLM practices in farming areas resulted in substantial amounts of sediment loss, and hence very little sediment retention. The terrace and grass strips showed significant differences in the retention capacity of sediment compared to the control. The combination of both terrace and grass strips also indicated a higher ability to retain sediment (Figure 5) than all other treatments. Similar trends were observed for soil moisture storage for all the treatments (Figure 5).

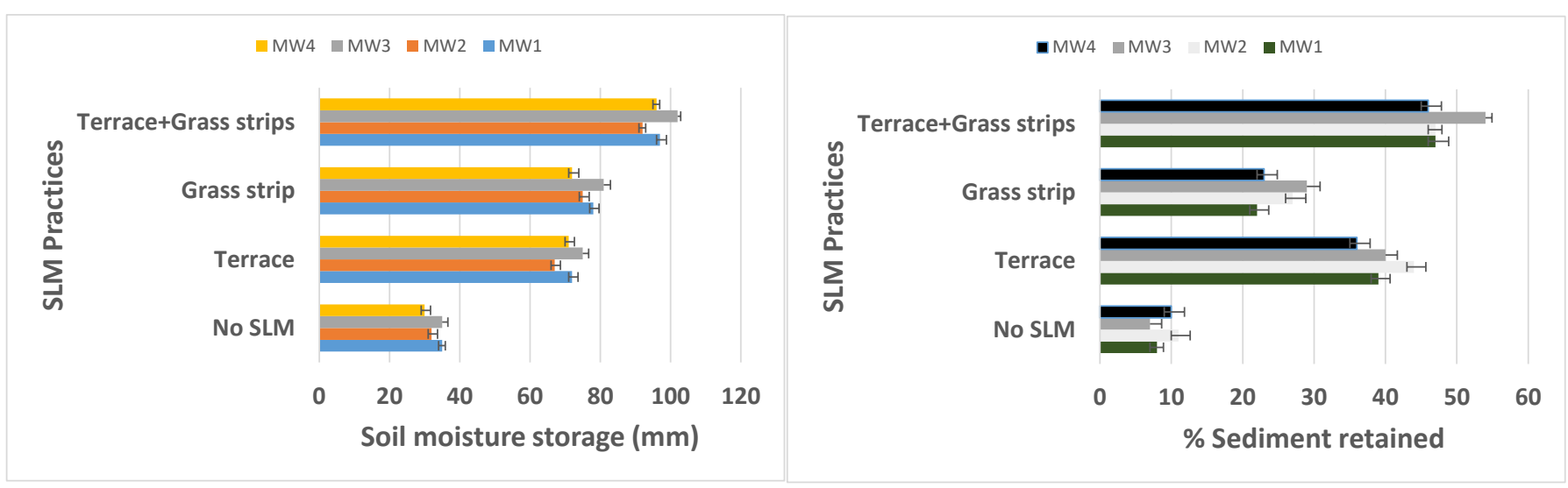

(A)

(B)

Figure 5. Variation of sediment retained in the landscape (A) and soil moisture storage (B) with different SLM practices across four micro-watersheds in the Upper Tana Basin. (Data variation depicted with Standard Error bars).

\subsection{Human Condition}

The control areas that did not have SLM options showed substantial differences $(p<0.05)$ when compared to the areas with SLM options over time and space (Table 2). The farms without SLM produced less food and had less calorific intake and protein compared to areas with SLM practices.

\subsection{Social}

Over a duration of 3 years (2015-2017), through field days, 240 female and 310 male farmers participated in the evaluation of the SLM treatments. During field days, the 
farmers evaluated the experimental plots with treatments based on visual observations from sediment retention traps in the landscape, crop vigor and appearance, and overall percentage of soil deposited in the traps for each of the treatments. In the context of terraces and grass strips, women generally ranked terraces much lower (18\%) compared to men $(27 \%)$; yet they ranked grass strips much higher $(29 \%)$ compared to men $(22 \%)$.

\subsection{Assessing Sustainability}

Sustainability was assessed at the micro-watershed level where varying trends were observed across the four micro-watersheds MW1 through MW4. There was a trend observed across all four micro-watersheds, with the combination of the grass and terrace having higher values than grass alone and terrace alone, and areas without SLM scoring the least. The Productivity domain for both micro-watersheds 3 and 4 had lower values than micro-watersheds 1 and 2. In addition, there were similar trends observed for both the grass and terrace treatments for micro-watersheds 3 and 4 . Based on results presented in Figure 6, micro-watershed 1 and 2 recorded higher sustainability indices than microwatersheds 3 and 4 for areas with no SLM treatments (Figure 6). For areas where SLM was practiced, the results were within the expected range.

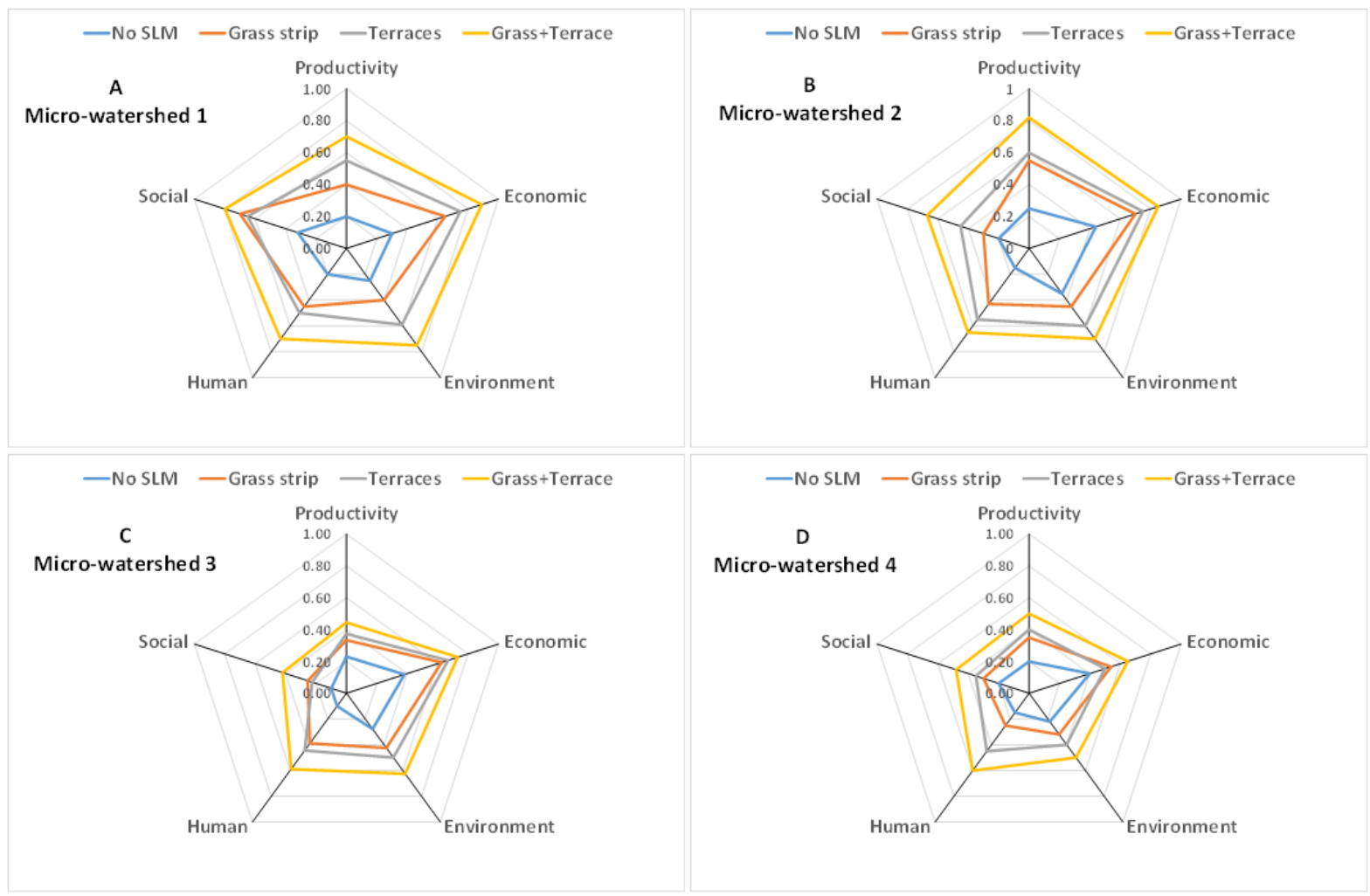

Figure 6. Spider plots representing the variation of sustainable land management interventions across the four microwatersheds in the Upper Tana Basin with the five domains of sustainable intensification assessment framework (Productivity, Economic, Environmental, Human, and Social).

Generally, across the four micro-watersheds, the three treatments-grass, terraces, and the combination of grass and terrace- - had higher sustainability indices than the control areas with no SLM options (Figure 7). The sustainability indices for micro-watersheds 3 and 4 registered values below the sustainability threshold of 1 for the control areas with no SLM practices, yet these were above 1 for micro-watersheds 1 and 2. (Figure 7). 


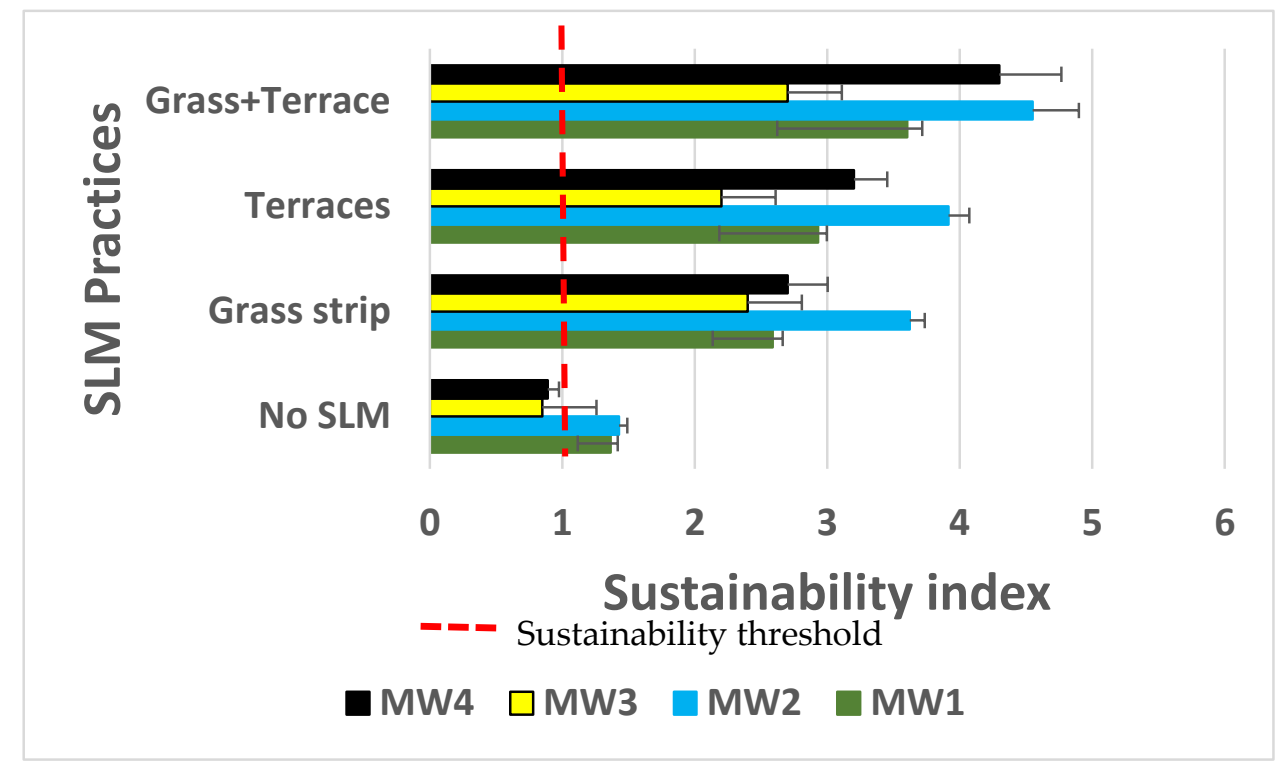

Figure 7. Sustainability index as affected by SLM practice in the Upper Tana Basin of Kenya. Bars represent standard errors.

\section{Discussion}

The terraces and forage grass strips had higher yields than the control areas without SLM practices, and the combination of forage grass strips and terraces showed the highest yield levels. The retention of soil in the landscape allowed for improved infiltration of water, and this resulted in a higher recharge of moisture in the root zone, that translated into higher yields. Narratives from FGDs showed that most farmers considered the use of SLM practices as a means of increasing crop production and income and not an end in itself, which suggests that there is a strong focus on short-term benefits. It is critical to consider the biophysical aspects in relation to crop-yield-generated income. In the central Kenyan highlands, soil conservation technologies such as terraces and green manure have been demonstrated to contribute to an increase in yield [16]. Dominguez-Hernandez et al. [17] reported that the most influential attribute for measuring the sustainability of agricultural technology is the productivity domain, as the yields determine how efficient the production system utilized is, which in turn influences other domains.

Wanyonyi [18] cited a sediment reduction of $80 \%$ in siltation following the introduction of SLM practices in the Masinga Reservoir catchment. In addition to conservation measures on farmland, it was also reported that the reforestation of landscapes above $1850 \mathrm{~m}$ above sea level may result in a $7 \%$ decrease of downstream sedimentation in the Masinga reservoir [19]. As evidenced in this study, forage grass strips and terraces are capable of controlling soil and nutrient losses while simultaneously conferring the needed landscape benefits and a sustainable maintenance of food security among smallholder farmers.

The economic gains associated with forage grass strips and terraces were not evident in the first year of the study due to the labor costs associated with the establishment of the technology, but on-going returns for labor and material inputs are not short-term and are only realizable after one year, they linger for a longer term.

Narratives from FGD transcripts revealed that the peri-urban proximity of farmers contributed to their greater exposure to information and this translates community restoration efforts into sustainable intensification gains for smallholder farmers in these landscapes.

As indicated from Table 2, the social dynamics between men and women were different, with women generally preferring grass strips compared to terraces, which had higher preference by men. This was likely due to the associated higher labor demands for terraces than labor demands for grass strips. The labor requirements for the annual maintenance of the SLM structures differed from one SLM practice to another, with the terraces presenting higher labor demands and the grass strips a lower demand for annual maintenance. This 
was partly because once the grass strips are established very little labor is required for their maintenance, as they are self-reinforcing. This finding corroborates that of Tenge et al. [20], where the major costs of implementing SLM were associated with terraces and were related to labor rather than the tools that are often provided as incentives for supporting farmers when conducting SLM practices in the landscape.

Another interesting variation observed between men and women was the way things were valued: for example, women looked at forage biomass in the context of milk production for nutrition, while men considered social prestige and looked at it along the value chain as fodder quantity for sale. Men did not rank or prioritize nutrition; they claimed that with sufficient money one could have a wider preference on what to eat. However, research has shown that while increased household income does tend to improve caloric intake, an increase in income does not necessarily result in better household nutrition [21]. As a result, increasing income may require other interventions to address food security challenges at the household level [22].

Areas with no SLM have farmers that produced less but consumed most of their food produce and barely had any surplus to sell. For all micro-watersheds MW1-MW4, SLM households consistently sold more of the farmland food produced than they consumed. This aspect has implications on the livelihood options of farmers. The interventions with SLM offered viable livelihood options for farmers while at the same time meeting their food and nutritional security needs compared to those without SLM, that lacked the purchasing power due to the lower production hence market sales of their produce.

\section{Conclusions}

The main conclusions are that, depending on the management regime, crop type, rainfall, local soil, and terrain, SLM practices: Increase soil retention in the landscape by about $20-45 \%$ (0.3-1.5 million ton/year); Improve water infiltration within cropland by $27-45 \%$ (108-180 $\mathrm{mm}$ per year), and reduce the unproductive evaporation of water from the soil surface by up to $15 \%$ (70 mm/year), translating into a water gain of about $400 \mathrm{~mm} / \mathrm{ha} /$ year. The social rankings of SLM practices between men and women revealed that men are more likely to prioritize soil and water conservation measures that give them social prestige and economic gains. This is likely related to the labor demands associated with achieving soil fertility, making contours, as well as land tenure-because, overall, men have a much more secure land tenure. This in turn points to the need for promoting laborand gender-friendly SLM options that can be used in combination (e.g., forage grass strips and terraces) as a means to maximize efficiency, spread risk, and provide diversity, which in turn allows for an easier farmer uptake, adoption, and scaling of SLM options. The SIAF lens shows evidence that landscape restoration interventions can be profitable and sustainable, but they need to consider specific contexts tailored for the right agro-ecologies and target audiences.

Author Contributions: Conceptualization, F.K. and A.R.N.; methodology, All Authors; formal analysis, F.K.; investigation, J.G., K.N.; data curation, F.K. and A.R.N.; writing-original draft preparation, All authors; visualization, F.K.; All authors have read and agreed to the published version of the manuscript.

Funding: The CGIAR Research Program on Water, Land and Ecosystem (WLE) funded this research. We also appreciate the funding from the United States Agency for International Development, with the grant number ARG\#: AID-BFS-G-11-00002, that offered support toward the development of the thought leadership on the Sustainable Intensification Assessment Framework.

Institutional Review Board Statement: Not applicable.

Informed Consent Statement: The details regarding data supporting reported results can be found at this link as a publicly archived dataset that is analyzed: https:/ / drive.google.com/drive/folders / 1NIE8gx_nLh9WU_tGM-NA1CSr6bNBSVhY?usp=sharing (accessed on 15 July 2021).

Data Availability Statement: Not applicable. 
Acknowledgments: We greatly appreciate the support provided from The Nature Conservancy (TNC) and various Partners in the Upper Tana Basin. We are immensely grateful for the collaboration received from the smallholder farmers that permitted the success of this work.

Conflicts of Interest: The authors declare no conflict of interest.

\section{References}

1. Thomas, D.B.; Eriksson, A.; Grunder, M.; Mburu, J.K. (Eds.) Soil and Water Conservation Manual for Kenya; Soil and Water Conservation Branch, Ministry of Agriculture, Livestock Development and Marketing: Nairobi, Kenya, 1997.

2. WOCAT. Where the Land is Greener-Case Studies and Analysis of Soil and Water Conservation Initiatives Worldwide; Linger, H., Critchley, W., Eds.; CTA Publishing: Wageningen, The Netherlands, 2007.

3. Kauffman, J.H.; Droogers, P.; Odada, E.; Macharia, P.N.; Gicheru, P.; Dijkshoorn, J.A. Green and Blue Water Services and Assessment of Improved Soil and Water Management Scenarios Using an Integrated Modelling Framework; Green Water Credits Report 3; ISRIC-World Soil Information: Wageningen, The Netherlands, 2007.

4. Malesu, M.M.; Sang, J.K.; Oduor, A.R.; Odhiambo, O.J.; Nyabenge, M. Rainwater Harvesting Innovations in Response to Water Scarcity: The Lare Experience; World Agroforestry Centre ICRAF: Nirobi, Kenya, 2006; 52p.

5. Woldearegay, K.; Tamene, L.; Mekonnen, K.; Kizito, F.; Bossio, D. Fostering food security and climate resilience through integrated landscape restoration practices and rainwater harvesting/management in arid and semi-arid areas of Ethiopia. In Rainwater-Smart Agriculture in Arid and Semi-Arid Areas; Springer: Cham, Switzerland, 2017.

6. Maingi, J.K.; Marsh, S.E. Assessment of environmental impacts of river basin development on the riverine forests of eastern Kenya using multi-temporal satellite data. Int. J. Remote Sens. 2001, 22, 2701-2729. [CrossRef]

7. Panafcon, D.C. Upper Tana Catchment Study; World Bank: Washington, DC, USA, 2007.

8. KenGen. Upper Tana Catchment Management Project; KenGen: Nairobi, Kenya, 2008.

9. Musumba, M.; Grabowski, P.; Palm, C.; Snapp, S. Guide for the Sustainable Intensification Assessment Framezork; Kansas State University: Manhattan, NY, USA, 2017.

10. TNC (The Nature Conservancy). Upper Tana-Nairobi Water Fund Business Case; Version 2; The Nature Conservancy: Nairobi, Kenya, 2015.

11. Dijkshoorn, J.A.; Macharia, P.N.; Huting, J.R.; Maingi, P.M.; Njoroge, C.R.K. Soil and Terrain Conditions for the Upper Tana River Catchment, Kenya. (Ver 1.1).Wageningen: ISRIC—World Soil Information. No. Green Water Credits Report 11. ISRIC Report 2010/09b. 2011. Available online: www.isric.org/isric/Webdocs/Docs/ISRIC_Report_2010_09b.pdf (accessed on 10 December 2020).

12. Hunink, J.E.; Niadas, I.A.; Antonaropoulos, P.; Droogers, P.; de Vente, J. Targeting of intervention areas to reduce reservoir sedimentation in the Tana catchment (Kenya) using SWAT. Hydrol. Sci. J. 2013, 58, 600-614. [CrossRef]

13. Abdul Rahman, N.; Larbi, A.; Kotu, B.; Kizito, F.; Hoeschle-Zeledon, I. Evaluating Sustainable Intensification of Groundnut Production in Northern Ghana Using the Sustainable Intensification Assessment Framework Approach. Sustainability 2020, 12, 5970. [CrossRef]

14. USDA. 2020. Available online: https://ndb.nal.usda.gov/ndb/foods/show/16087 (accessed on 21 January 2021).

15. Statistical Analysis System (SAS) Institute. Base SAS 9.4 Procedures Guide; SAS Institute Inc.: Cary, NC, USA, 2013.

16. Ekbom, A. Soil Properties and Conservation Technologies in Agricultural Production-A Case Study of Kenya's Central Highlands; University of Göteborg: Göteborg, Sweden, 2007.

17. Dominguez-Hernandez, M.E.; Zepeda-Bautista, R.; Valderrama-Bravo, M.D.C.; Dominguez-Hernandez, E.; Hernandez-Aguilar, C. Sustainability assessment of traditional maize (Zea mays L.) agroecosystem in Sierra Norte of Puebla, Mexico. Agroecol. Sustain. Food Syst. 2018, 42, 383-406. [CrossRef]

18. Wanyonyi, S.W. Sediment Management in Masinga Reservoir, Kenya; University of Agricultural Sciences (BOKU): Vienna, Austria, 2002; 173p.

19. Jacobs, J.; Angerer, J.; Vitale, J.; Srinivasan, R.; Kaitho, R.; Stuth, J. Exploring the Potential Impact of Reforestation on the Hydrology of the Upper Tana River Catchment and the Masinga Dam, Kenya; Draft Report; Texas A\&M University: College Station, TX, USA, 2003.

20. Tenge, A.J.; De Graaf, J.; Hella, J.P. Financial efficinency of major soil and water conservation measures in West Usambara Highland, Tanzania. Appl. Geogr. 2005, 25, 348-366. [CrossRef]

21. Shenggen, F.; Brzeska, J. The Nexus between Agriculture and Nutrition: Do Growth Patterns and Conditional Factors Matter? IFPRI Research Brief; International Food Policy Research Institute: Washington, DC, USA, 2011. Available online: https://www. marketlinks.org/resources/nexus-between-agriculture-and-nutrition-do-growth-patterns-and-conditional-factors-matter (accessed on 15 July 2021).

22. FDDF. Available online: https://www.cambridge.org/core/journals/journal-of-nutritional-science/article/effect-of-nutritionbehaviour-change-communication-delivered-through-radio-on-mothers-nutritional-knowledge-child-feeding-practices-andgrowth/AC14414F381003DF1CB87CF46CD4033E (accessed on 15 July 2021). 